\title{
MAXIMUM POWER EXTRACTION USING SWITCHED PV ARRAY UNDER PARTIAL SHADING
}

\author{
Pooja $M^{1}$, Mohd. Z. A. Ansari \\ ${ }^{1}$ Student, Dept. of EEE, Ghousia College of Engineering, Ramanagaram, Karnataka, India(Affiliated ot VTU, \\ Belagavi) \\ ${ }^{2}$ Member IEEE, Professor and Head, Dept.of EEE, Ghousia College of Engineering, Ramanagaram, Karnataka, India( \\ Affiliated ot VTU, Belagavi)
}

\begin{abstract}
This paper aims at maximizing the extraction of power from a $P V$ array under partial shading condition. The proposed topology of a switched PV arrangement can be implemented on an existing system for a domestic purpose. The proposed scheme is compared witch traditional PV technology with variation in isolation for same operating conditions. The proposed scheme is simple, compact lower size and cost-effective. Simulationresult shows that the proposed system has an enhanced power in comparison with the traditional PV technology.
\end{abstract}

Keywords—Switched PV arrays, Component,Partial shading, domestic PV application.

\section{INTRODUCTION}

Extracting a power from a source in case of partial shading condition is an important criteria. Usually with no shadowing condition maximum power is obtained where in shadowing condition variation in power peaks can be seen. In order to track the maximum power point a global MPPT tracking system is used. A design of the solar PV module is modeled and its $\mathrm{P}(\mathrm{V})$ and I (V) characteristic is studied at standard test condition and with variation isolation. Using MATLAB2013/Simulink [1].

A MPPT technique used is $\mathrm{P} \& \mathrm{O}$ algorithm [2]. It is compatible with the PV technology and is fast compared to DPP Structure [3] as it is cost-effective and less number of equipment is used. Based on the type of inverter used, PV system can be classified as central inverter, string inverter, module integrated inverter and differential power processing [4] as shown in Figure1. In the traditional arrangement we can see the mismatch in power during shadowing condition. In this paper new switching arrangement is being introduced with simulation outcome. A mathematical comparison shows that maximum power is enhanced effectively in the proposed system. The chief advantage of the proposed system is ease of use and implementation, efficient and less price and less wear on equipment which is much suited for domestic users.

\section{PROPOSED SWITCHED CONCEPT}

In the proposed idea each PV chord is divided into 2 segments and it is connected through the diode and switch as shown inFigure 2. The proposed concept operates in two states, state -1 when the switch is closed and state two when the switchis open. During state - 1 all switches are closed and a maximum voltage of whole chord is obtained where as in state - 2 all switches are open and each segment of a whole chord will contribute its maximum voltage. Hence voltage at state - 2 is almost twice the voltage of state - 1. Sepic converter used will provide a required power to the load regardless of change in input voltage.

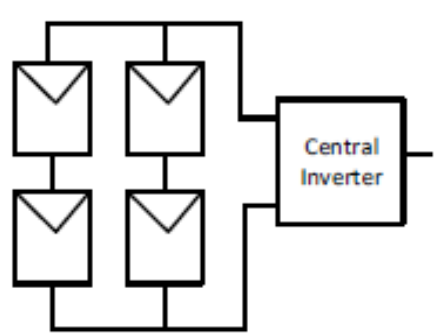

(a)

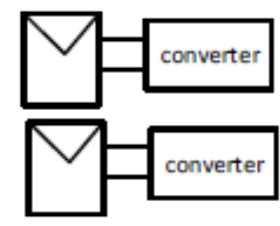

(c)

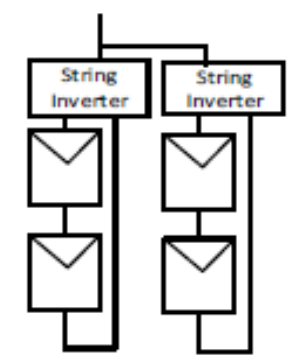

(b)

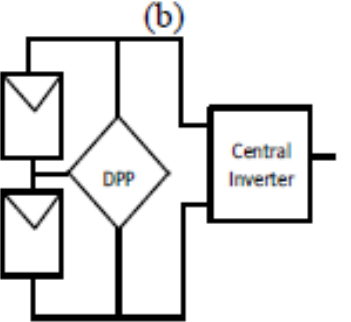

(d)
Fig.1. Different PV Technology

\section{PHOTOVOLTAIC ARRAYS AND ITS CHARACTERISTICS}

A light energy is converted to electrical energy with the help of a PV cell. The modeling of PV cells is done based on weather data which is dynamic in nature they are temperature and irradiance. The modeling of PV cell is carried out by considering data provided as per in Table 1 by MITSUBISHI ELECTRIC. The built in model is simulated in the MATLAB/Simulink environment. The obtained $\mathrm{P}(\mathrm{V})$ and $\mathrm{I}(\mathrm{V})$ characteristics are analyzed. 


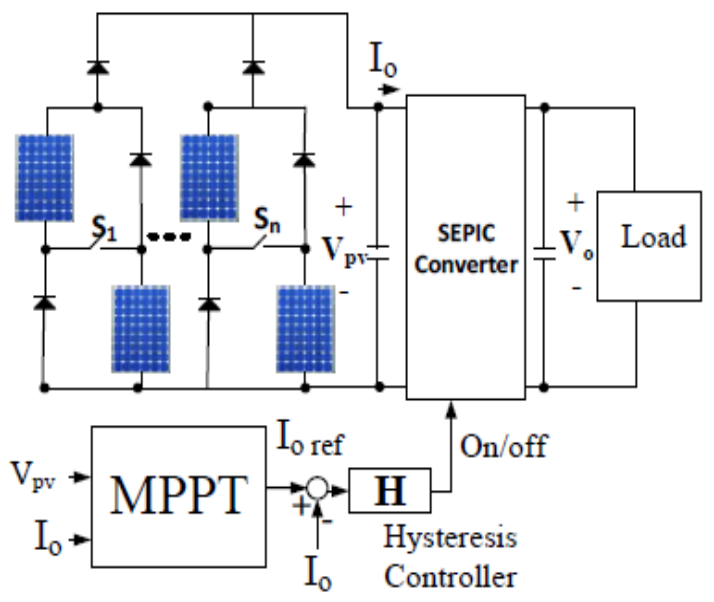

Fig.2. Proposed Switched System

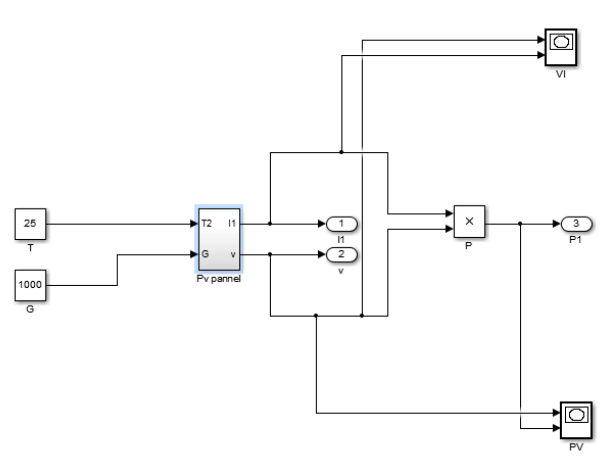

Fig.3. Solar PV Subsytem Model

The masked model is presented here in the Figure 3.P(V) and $I(V)$ characteristics of single cell, with different irradiance and different temperature at standard temperature condition (STC) constant temperature and irradiance of themodel PVUD19MF5 characteristic are studied and analyzed. The ir-radiation is varied from $250-1000$ and temperature from $0-75$ degree celsiusat STC of temperature and isolation respectively. We can observe that with more illumination maximum power is obtained and with the rise in temperature power output will decrease. These can be seen in $\mathrm{P}(\mathrm{V})$ and $\mathrm{I}(\mathrm{V})$ characteristic graphs (Figures 4-8).

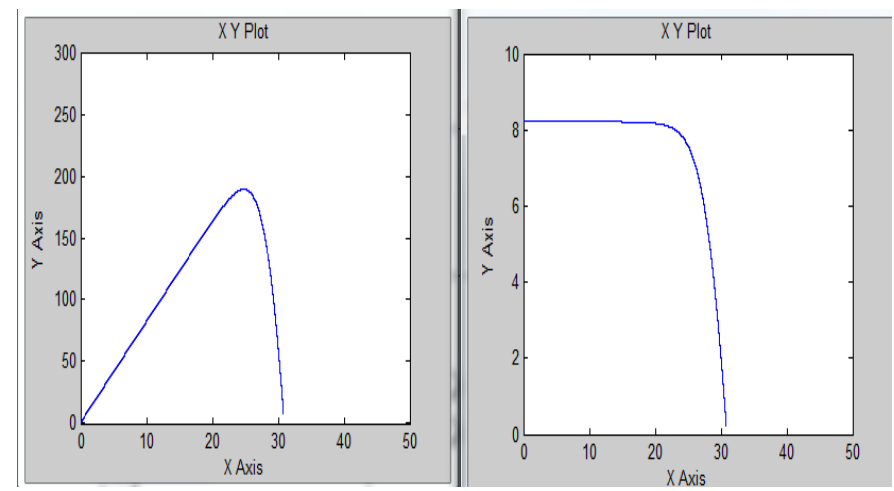

Fig.4. Plot of $\mathrm{P}(\mathrm{V})$ and $\mathrm{I}(\mathrm{V})$ at STC

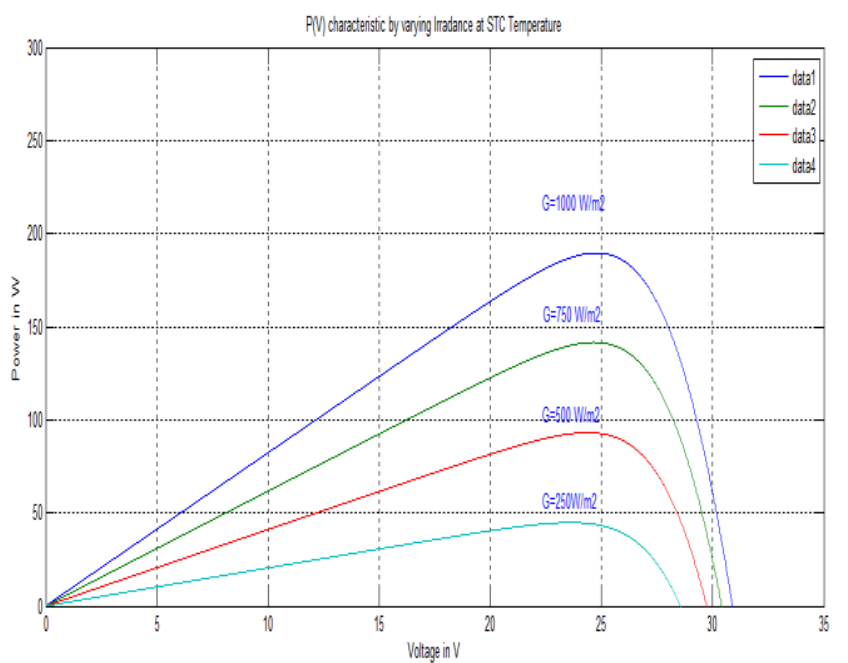

Fig.5. P(V) Characteristic by Varying Irradance at STC of Temperature

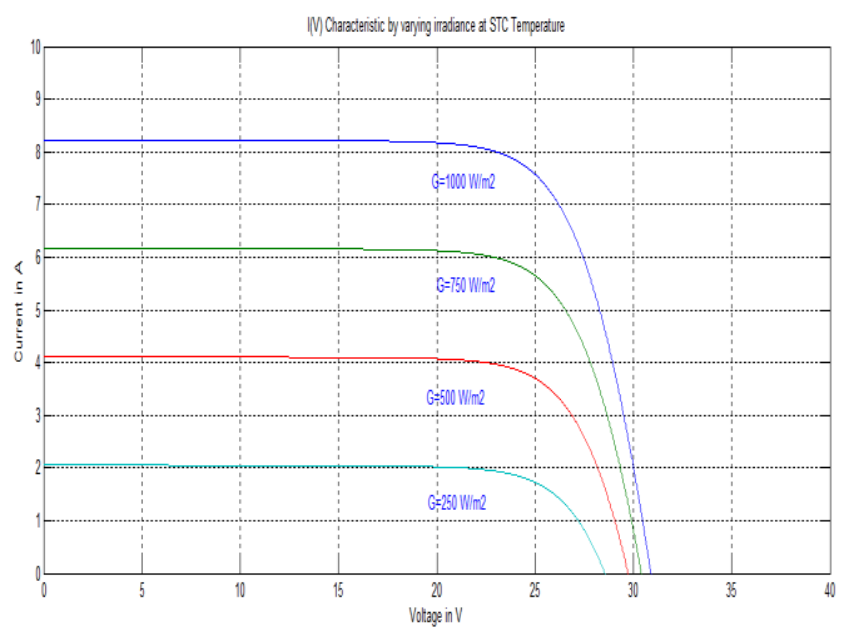

Fig.6. I(V) Characteristic by Varying Irradance at STC of Temperature

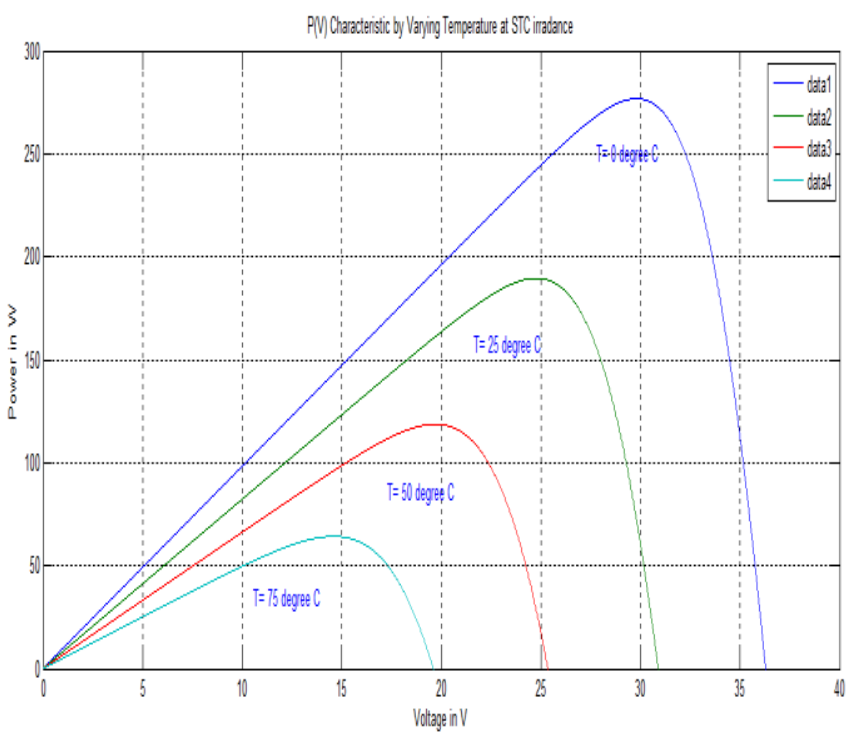

Fig.7. $\mathrm{P}(\mathrm{V})$ Characteristic by Varying Temperature at STC of Irradiance 


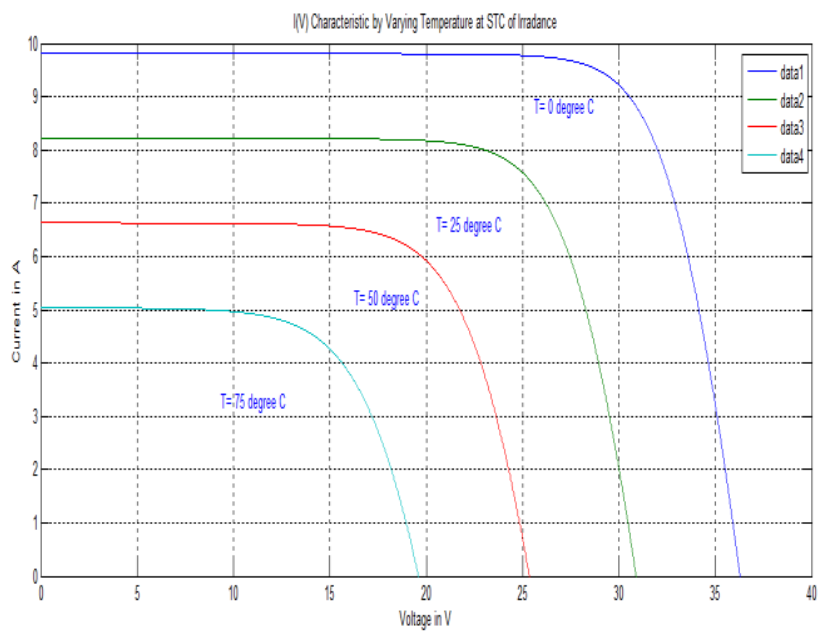

Fig.8. I(V) Characteristic by Varying Temperature at STC of Irradiance

Table.1. 190W Model Data

\begin{tabular}{|l|l|}
\hline Parameters & Values \\
\hline $\operatorname{Pmp}(\mathrm{w})$ & 190 \\
\hline $\operatorname{Imp}(\mathrm{A})$ & 7.71 \\
\hline $\operatorname{Vmp}(\mathrm{V})$ & 24.7 \\
\hline $\operatorname{Isc}(\mathrm{A})$ & 8.23 \\
\hline $\operatorname{Voc}(\mathrm{V})$ & 30.8 \\
\hline $\operatorname{Rs}(\Omega)$ & 0.20758 \\
\hline $\operatorname{Rp}(\Omega)$ & 975.6 \\
\hline$\mu \operatorname{sc}(\mathrm{k})$ & $1.3 \mathrm{e}-3$ \\
\hline Noct ${ }^{\circ} \mathrm{C}$ & 47.5 \\
\hline Ns & 50 \\
\hline
\end{tabular}

\section{MAXIMUM POWER POINT TRACKING}

To extract a maximum power from a solar array MPPT algorithm shown in Figure 9 is used.

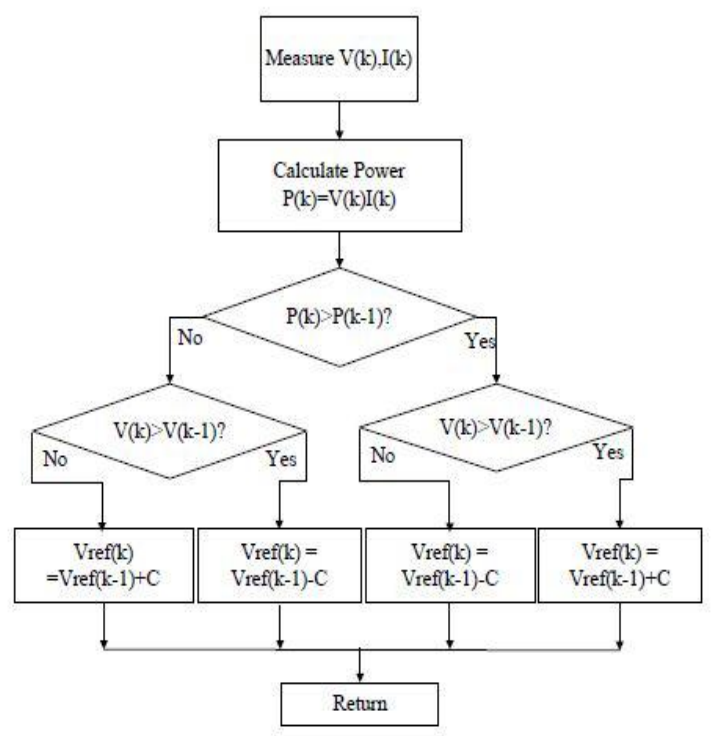

Fig.9. Flowchart to Show Procedure of P\&O MPPT Technique
Maximum power point depends on solar-radiation and temperature. The global MPP will vary as temperature and isolation changes. In this paper perturb and observe technique is used to point the global maximum power. The advantage of this technique is its simplicity and can be improvised very easily. In this algorithm output voltage and current are measured and is subtracted from a previously measured value. If the change in power is not seen then it is an MPP. If there is the change in power than the duty cycle of the converter will be increased or decreased to move the power point forcefully towards the global point. The Figure10 below shows the change in duty cycle. Its control action is given in Table 2 .

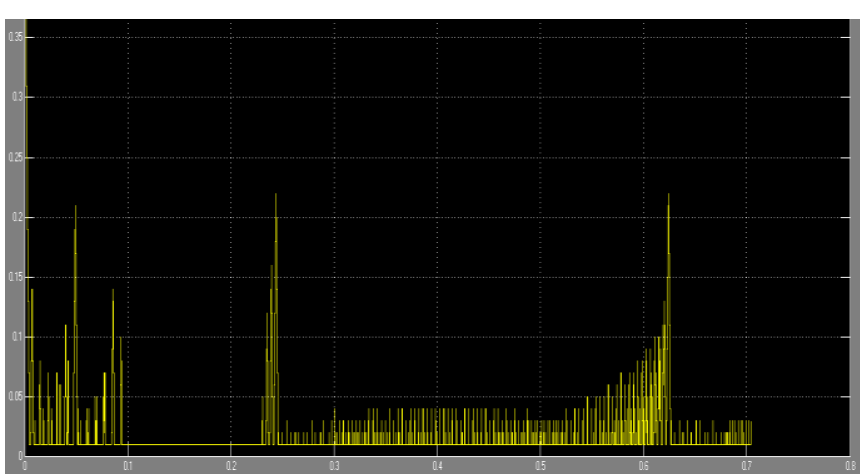

Fig.10. Change in Duty Cycle to Shift to Maximum Power Point

Table.2.Control Action of Duty Cycle

\begin{tabular}{|c|c|c|c|}
\hline Case & Conditions & Position & Control action \\
\hline 1 & $\Delta \mathrm{p}_{\mathrm{K}}>0, \mathrm{v}_{\mathrm{K}}>0$ & Left of MPP & Increase $\delta$ \\
\hline 2 & $\Delta \mathrm{p}_{\mathrm{K}}>0, \mathrm{v}_{\mathrm{K}}<0$ & Right of MPP & Decrease $\delta$ \\
\hline 3 & $\Delta \mathrm{p}_{\mathrm{K}}<0, \mathrm{v}_{\mathrm{K}}>0$ & Right of MPP & Decrease $\delta$ \\
\hline 4 & $\Delta \mathrm{p}_{\mathrm{K}}<0, \mathrm{v}_{\mathrm{K}}<0$ & Left of MPP & Increase $\delta$ \\
\hline
\end{tabular}

\section{PROPOSED SYSTEM SIMULATION AND RESULTS}

The Simulink model built for a proposed system is as shown in Figure 11. A PV array, withtwochord is considered. The data of each model is as mentioned in Table 1. Here it is tested for four different shading condition at STC. The shadowing pattern is as mentioned in Table 3.

Table.3 Shadowing Pattern

\begin{tabular}{|l|l|l|l|l|}
\hline $\begin{array}{l}\text { PV } \\
\text { Array } \\
\text { Number }\end{array}$ & $\begin{array}{l}\text { Pattern } \\
\mathbf{1}\end{array}$ & $\begin{array}{l}\text { Pattern } \\
\mathbf{2}\end{array}$ & $\begin{array}{l}\text { Pattern } \\
\mathbf{3}\end{array}$ & $\begin{array}{l}\text { Pattern } \\
\mathbf{4}\end{array}$ \\
\hline 1 & 1000 & 1000 & 1000 & 1000 \\
\hline 2 & 1000 & 1000 & 1000 & 500 \\
\hline 3 & 1000 & 1000 & 500 & 500 \\
\hline 4 & 1000 & 500 & 500 & 500 \\
\hline
\end{tabular}

In case of no shadowing condition, maximum power can be obtained in all types of techniques.But in case of shadowing condition maximum power will vary from one technique to another technique. Here a DC load of $5 \mathrm{KW}$ is considered. 
The output power fed to DC load is compared between a traditional method and proposed methodology and the result obtained is tabulated in Table 4 . We can see that the output power in watts is maximum in case of the proposed system and state -2 is best suited during shadowing condition.
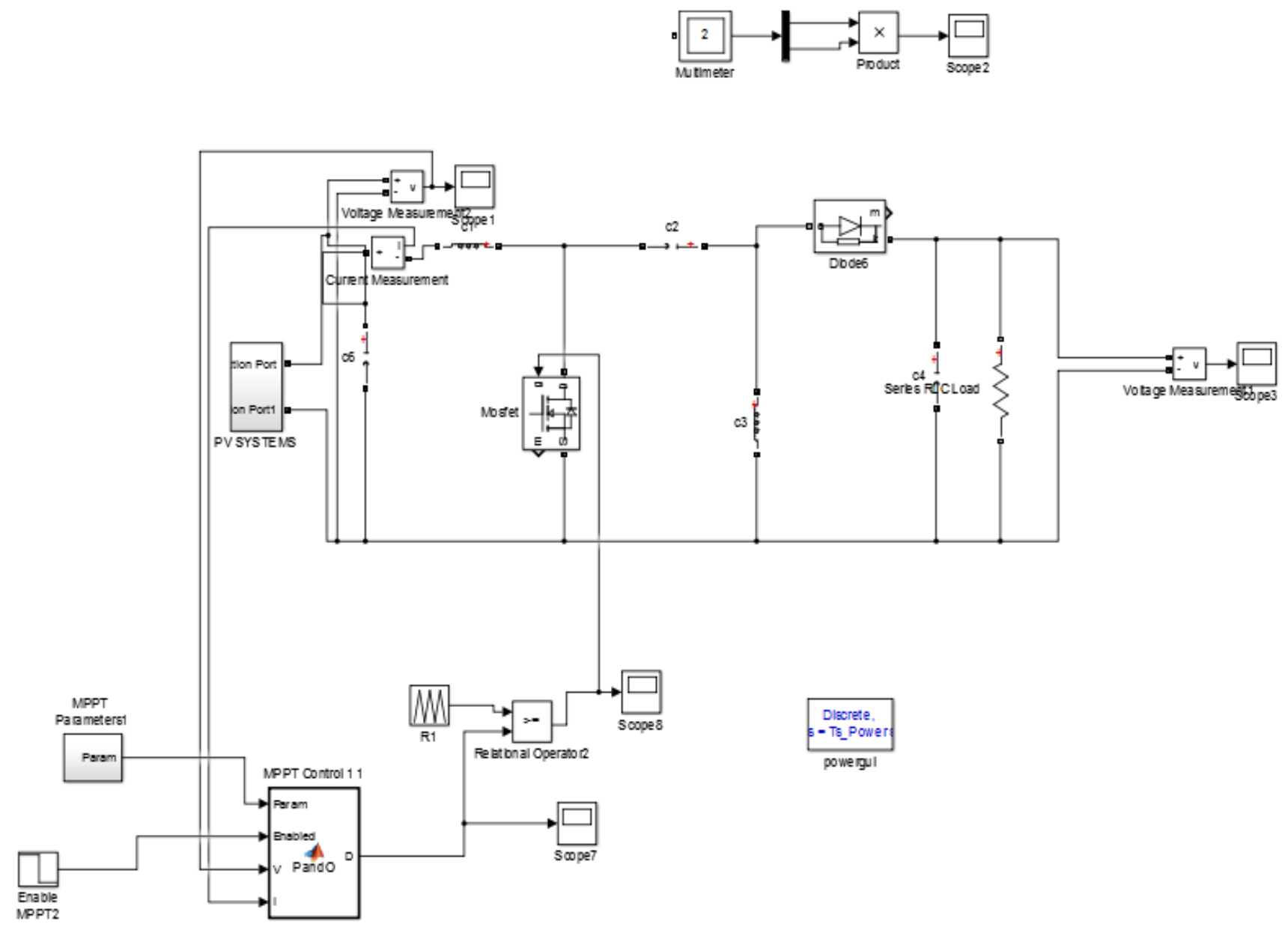

Fig. 11. Proposed System Simulation Block

Table.4. Comparison of Power Output

\begin{tabular}{|l|l|l|l|l|}
\hline $\begin{array}{l}\text { PV } \\
\text { Technology }\end{array}$ & $\begin{array}{l}\text { Pattern } \\
\mathbf{1}\end{array}$ & $\begin{array}{l}\text { Pattern } \\
\mathbf{2}\end{array}$ & $\begin{array}{l}\text { Pattern } \\
\mathbf{3}\end{array}$ & $\begin{array}{l}\text { Pattern } \\
\mathbf{4}\end{array}$ \\
\hline Conventional & 4800 & 3039 & 1400 & 1290 \\
\hline $\begin{array}{l}\text { Proposed state } \\
1\end{array}$ & 4990 & 4430 & 3842 & 2330 \\
\hline $\begin{array}{l}\text { Proposed state } \\
2\end{array}$ & 5000 & 4900 & 4895 & 4070 \\
\hline
\end{tabular}

Power output delivered to load at STC using conventional topology is shown in Figure 12 while that with the proposed system is shown in Figure 13.

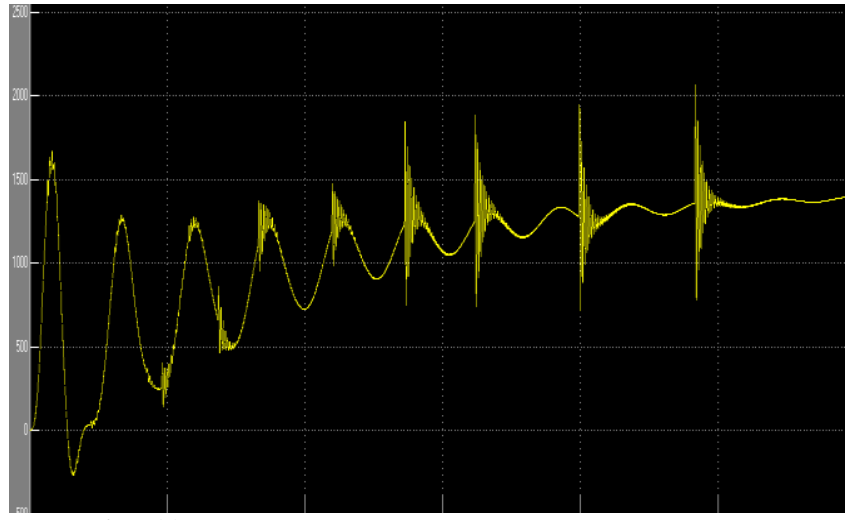

Fig. 12. Power Output Delivered To Load at STC (Conventional) 


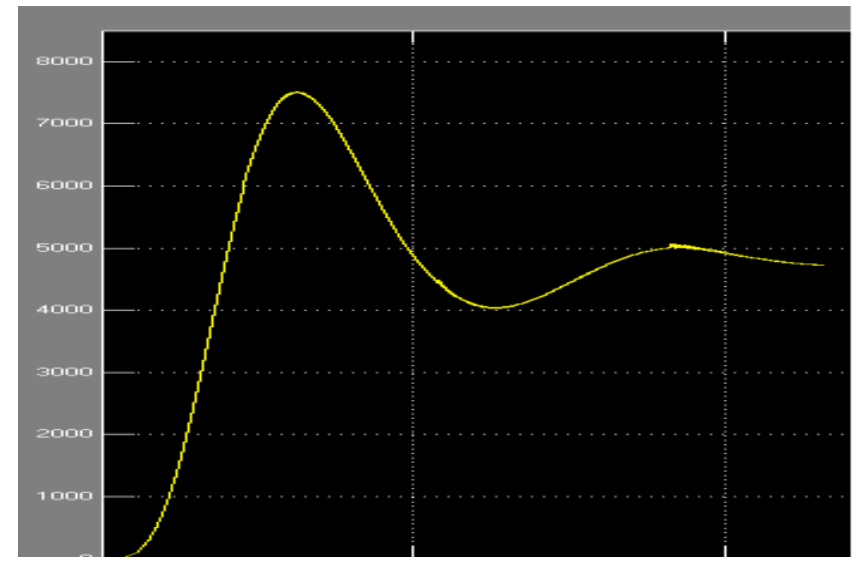

Fig. 13.Power Output Delivered To Load at STC (Proposed)

\section{CONCLUSION}

In this paper proposed technology is being valued. The switched technique used will enhance a maximum power under shadowing condition. The proposed system is compared with other conventional PV system showing a better performance. The main advantage is that, it can be implemented for an existing system, lower size, reduced complexity and equipments which in turn are more reliable and ease of maintenance.

\section{ACKNOWLEDGEMENT}

The authors would like to thank the authorities of Ghousia College of Engineering, Ramanagaram, for all support and encouragement received in carrying out this work.

\section{REFERENCES}

[1] HabbatiBellia, RamadaniYoucef, and Moulay Fatima, "A detailed Modeling Of Photovoltaic module using MATLAB," NRIAG Journal of Astronomy and Geophysics, pp. 53-61, May 2014.

[2] G. Smita Ganesh Pachpande,and Prof. Pankaj H. Zope, "Studying the effect of shading on Solar Panel using MATLAB," International Journal of Science and Applied Information Technology,Vol.1,No. 2,May-June 2012.

[3] P.S. Shenoy, K.A.Kim, B.B. Jhonson, and P.T. Krein "differential Power Processing for increased energy production and reliability of photovoltaic system", IEEE trans on Power Electronics, Vol.28, No. 6, June 2006.

[4] J.M.A. Myrzik, and M. Calais, "String and module integrated inverters for single phase grid connected photovoltaic systems-A review", 2013 IEEE Bologna Power Tech Conference, Vol. 2, 2003. 